\title{
Konutlarda İç Mekan İle Mobilya Etkileşimi Bağlamında Mobilyaya Dair Özelliklerin Incelenmesi*
}

\author{
Selin Üst
}

\section{Öz}

Çok sayıda işlevin bir araya geldiği konut iç mekân tasarımı, yoğun bir programlamayı ve çözümü gerektirmektedir. Nüfus ve refah artışı, kentlere göç ve sosyo-ekonomik gelişmelere paralel olarak mekan ihtiyacı hızla değişmektedir. Konut sektöründeki kavramsal değişimler sonucu, küçülen mekânlarda daha esnek ve fonksiyonel kullanım ihtiyacı, mobilyaya olan talebi sürekli canlı tutmaktadır.

Bu çalısmada, konut tasarım üretim süreci ile mobilya tasarım-üretim süreci arasındaki çok boyutlu ilişkiler ağına vurgu yapılarak Türkiye ölçeğinde "mobil hane halkı" ve "kira konut" kavramları üzerinden konut içinde kullanılan mobilyalar işlevsellik ve tasarım özellikleri bakımından incelenmektedir.

Anahtar kelimeler: Mobilya, Konut, iç Mekan Tasarımı

\section{ANALYZING FURNITURE CHARACTERISTICS IN THE CONTEXT OF INTERACTION BETWEEN RESIDENTIAL INTERIORS AND FURNITURES}

\begin{abstract}
Designing residential interiors that consist of numerous functions requires intensive programming and design solutions. Need of space increases in direct proportion to population growth and prosperity, migration to cities and socio-economic developments. As a result of conceptual change in the housing sector, dwellings that become smaller have to be designed more flexible and functional. So the increase of the furniture design demand always keep alive.

This study discusses the multi-dimensional relationships between housing design-production process and furniture design-production process and analyzes the characteristics of the furniture used in residentials in Turkey by emphasizing the notions of "moving householdfamilies who move frequently" and "non owner occupied housing".
\end{abstract}

Keywords: Furniture, Dwelling, Interior Design

\footnotetext{
* Bu makale, Prof. Dr. Hasan Şener danışmanlığında, iTÜ Mimarlık Tasarım Programı'nda devam etmekte olan "Toplu Konutlarda İç Mekan ve Seri Üretim Mobilya Etkileşimi Üzerine Bir Araştırma” isimli doktora tez çalışması esas alınarak yazılmıştır.
} 


\section{Giriş}

Konut, en genel tanımıyla insanların korunma, barınma ve güvenlik gereksinimlerini karşılayan yapıdır. Konut, insanlığın en ilkel çağlarından itibaren, insanların kendilerini yırtıcı hayvanlardan, düşmanlardan, hava koşullarından korumak amacıyla sığındıkları, saklandıkları ve hayatlarını sürdürdükleri, günün olanak ve koşullarına göre şekillenen yaşama birimleridir.

Bu yaşama birimleri, kullanılan donatılar ile korunmanın dışında oluşan intiyaçlarına da cevap verebilecek şekilde giderek farklı niteliklere sahip mekanlardan oluşarak gelişmeye başlamıştır. İçinde bulunulan çevrelerin en karmaşık olanlardan birinin konut iç düzeni olduğunu söylemek mümkündür. Çok sayıda işlevin bir araya gelmesi, konut iç mekân düzeninde yoğun bir programlamayı ve çözümü gerektirmekte, bu noktada mekan içinde tercih edilen donatıların özellikleri önem kazanmaktadır.

Günümüz modern insanının 4+1, 3+1, 2+1 ve 1+1 konut 'çeşitlerinden' birini seçerek mobilya marketlerindeki seri üretim mobilya çeşitliliği ile evini döşediği düşünüldüğünde, konut iç mekan ile mobilya ilişkisinin önemi daha da ortaya çıkmaktadır. Ancak konut iç mekanları ile bu mekanlardaki yaşamsal faaliyetleri kolaylaştırması amacıyla üretilen mobilyaların uyumu; kiracılık, sık konut değiştirme, her konuta göre yeni mobilya alamama, fiyat öncelikli konut ve mobilya seçimi gibi pek çok sebepten dolayı sağlanamamaktadır.

Bu çalışmanın amacı, konut tasarım-üretim süreci ile mobilya tasarımüretim süreci arasındaki çok boyutlu ilişkiler ağına vurgu yaparak, Türkiye ölçeğinde "mobil hane halkı" ve "kira konut" kavramları üzerinden konut içinde kullanılan mobilyaların özelliklerini incelemektir. Çalışma, literatür taraması yoluyla toplanan verilerin içerik analizine dayanmaktadır. Best (1959) tarafından "mevcut kayıt ya da belgelerin, veri kaynağı olarak, sistemli incelenmesi" olarak tanımlanan bu yöntem, araştırmanın amacına yönelik kaynaklara ulaşmak ve probleme dair veri elde etmek için kullanılmıştır (Karasar, 2007).

Hane halkının mülkiyet biçimi, kiracı veya konut sahibi olma durumu, hareketlilik - mobil olma kararlarını ve konutta kalma sürelerini etkilemektedir. Kiracılar daha fazla konut değiştirir ve daha az süre konutlarında ikamet ederken, konut sahipleri ise daha az konut değiştirmekte, aynı konutta daha uzun süre kalmaktadır (akt. Karahan, 2009). 
"Türk ailesinin yaşadığı mekanlara ve konutlara ilişkin eğilimler" adlı araştırma raporuna göre, Türk halkının \%36'sının kiracı olduğu görülmektedir. Bu oran apartmanlarda \%50'lere çıkmakta, dolayısıyla ev değiştirme olgusu kaçınılmaz bir zorunluluk olarak ortaya çıkmaktadır (Başbakanlık Aile Araştırma Kurumu Başkanlığı, 1999).

$\mathrm{Bu}$ araştırmada; Türkiye genelinde evlendikten sonra 1-3 defa ev değiştirenlerin oranının \% 45, 4-10 defa değiştirenlerin oranının \% 20, hiç değiştirmeyenlerin oranının \%30 olduğu bildirilmektedir. Apartmanlarda yaşayan hane halkının \%4'ünün ise evini 10 kereden fazla değiştirdiği görülmektedir. Bu sonuçlara göre, apartman sakinlerinin dörtte üçünün mobil olma durumundan söz edilebilir (Başbakanlık Aile Araştırma Kurumu Başkanlığı, 1999). Mobil durumda olan bu hane halklarının kullandığı mobilyaların taşındıkları her konut ile uyumu yeni bir sorun teşkil etmektedir. Bu noktada konut içinde kullanılan mobilyaların özellikleri önem kazanmaktadır.

\section{Konut İç Mekan Mobilyalarının Tanımı ve Özellikleri}

Mobilya, mekanın iç düzenini sağlamak amacıyla yerleştirilen ve çeşitli gereksinimleri karşılayan öğedir, dolayısıyla konut iç mekan tasarımı ile yakından ilişkilidir. Ching (2007)'e göre mobilya, mimari ve mekân kullanıcıları arasında aracılık eder, iç mekân ve birey arasında biçim ve ölçek bazında geçişi sağlar, iç mekân etkinliklerine konfor ve kullanışlılık katarak, bu mekânları kullanışlı kılar. Duvar, döşeme, kolon, kapı, pencere gibi yapısal bileşenler kadar donatı ve aksesuarlar da mekân oluşturmada çok etkili rol oynar.

\subsection{Mobilyanın Tanımı}

İnsanın mekansal yaşam intiyaçlarını, alet ve eşyalar ile karşılamaya başladığı ilk çağlardan beri mobilya kavramından bahsedilebilir. Mobilya zaman içerisinde toplumların yaşam koşulları, uygarlık anlayışları ve estetik görüşlerine paralel değişim göstermiş ve farklı biçimler almıştır. Farklı kaynaklar, mobilya kelimesini aşağıdaki şekillerde tanımlamaktadır.

- Mobilya, oturulan, yemek yenilen, çalışılan, yatılan yerlerin döşenmesine yarayan taşınabilir eşyaya verilen genel ad, möble olarak tanımlamaktadır ${ }^{1}$.

- Mobilya, gündelik hayatın istisnasız her alanında kullanılan, oturma, yatma, yemek yeme, seyahat etme, dinlenme, çalışma ve her türlü eşyanın yerleştirilmesi ve korunması gibi birçok alanda kullanılan sabit ve taşınabilir eşyalara verilen ortak addır (Milliyet Hachette Axis 2000 Büyük Ansiklopesi,

I http://www.tdk.gov.tr 
1999).

- Mobilya kelimesi (hareketli olan anlamındaki mobilis'ten gelir) taşınmazların tersine taşınır olan (yeri değiştirilebilen) ve bir evi döşemede kullanılan her türlü eşyayı belirtir².

Mobilya, insanların oturma, yatma, çalışma, depolama gibi temel fiziksel gereksinimlerini sosyal ve kültürel boyutları ile ele alarak, güvenli ve konforlu bir şekilde gidermelerini amaçlayan elemanlar ve/veya sistemler olarak tanımlanabilir.

\subsection{Mobilyanın Özellikleri}

Donatının mekân içindeki yoğunluk ve organizasyonu, o mekânın yaşanabilirliğini, olumlu ya da olumsuz yönde etkileyebilir. Konut iç mekân tasarımda mobilyanın önemli bir girdi olarak değerlendirilmesi ne kadar önemli ise, mobilya tasarım sürecinde de konut iç mekan özelliklerinin dikkate alınması o kadar önemlidir. Herhangi bir uyumsuzluk durumu insan yaşamına dair psikolojik, sosyolojik ve ekonomik sonuçlar doğurur. Tasarımcıya düşen görev mekan-donatı ilişkisini doğru kurgulamaktır.

Bu çalışmada konut iç mekanında kullanılan işlevsellik ve tasarım, özellikleri bakımından iki ana başlık altında örneklerle incelenmiştir. Çalışmada, mülk, konut sahibi olma olanakları sınırlı olan toplumsal kesimin tercihi kira konut iç mekanları ile bu mekanlarda kullanılan mobilyaların uyum probleminden yola çıkıldığı için, mobil durumda olan bu hane halklarının konut mekanlarında kullandığı mobilyaların özelliklerini irdelemeye katkı sağlayacak iki ana başlık oluşturulmuştur.

\section{A. İşlevsel Özellikler}

Kiracı olma oranının oldukça yüksek olduğu, hane halklarının sıklıkla konut değiştirdiği Türkiye'de; mobilyanın içine konulduğu mekan ile uyumunun sorun teşkil ettiği bilinmektedir. Uyum sorununun çözümünde en önemli faktörlerden biri mobilyanın işlevsel özellikleridir. Aşağıda, mobilyanın işlevsel özellikleri; sabitlik/hareketlilik, işlevsel çeşitlilik, modülerlik, toplanabilirlik / boyut değiştirebilirlik / depolanabilirlik alt başlıkları altında incelenmektedir.

\section{Sabitlik-Hareketlilik}

Mobilyalar içinde bulundukları mekanlara ve bu mekanlardaki konumlarına göre biçimlenirler. Buna göre mobilyalar; çevrelerine bağımlı yani sabit 2 http://www.kulturvarliklari.gov.tr 
veya bağımsız yani hareketli olarak tasarlanabilirler.

Mekana bağımlı mobilyaya Geleneksel Türk Evi örneği ile başlamak doğru olacaktır. Türk Evi'nde görülen en önemli mekansal özellik, konutta bulunan odaların tüm fonksiyonları içeren hacimler şeklinde tasarlanmış olmasıdır. Türk Evinde, çok amaçlı kullanılan oda mekanının esneklik özelliği, seçilen mobilyalar ile sağlanmıştır. Esnekliği sağlayan mekansal çözümlerde farklı kullanımlara uygun sabit mobilyaların etkisi büyüktür. Her odada oturma, uzanma, yatma eylemlerine hizmet eden sedir ve odanın en az bir duvarını kaplayan dolap olmak üzere iki sabit donatı bulunmaktadır. Giysi, ev eşyası, yatak yorgan depolamanın yanı sıra yıkanma bölümü de sabit dolap ile birlikte çözümlenmiştir.
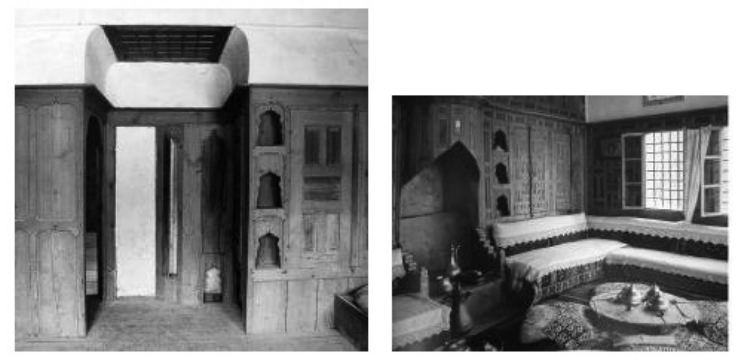

Şekil 1: Geleneksel Türk Evi (Günay,1998)

Sabit mobilyalar mekana özgü olarak tasarlandıkları için ait oldukları çevrenin, yani yapının bir parçası durumundadır. Konutta yaşayan hane halkları değişse dahi; sabit mobilyalar evin en kalıcı mobilyalarıdır. Gömme dolaplar, yere sabitlenmiş masalar, bankolar, mutfak banyo dolapları sabit mobilyalardır.

Mobil hane halklarının yaşam düzenlerinde mobilyaların farklı mekânlara uyum yeteneği önem kazanmaktadır. Bu anlamda, mobilyanın sabit olmaması ve mekân içerisinde yer değiştirebilme özelliği kullanııların mekanı istediklerişekilde düzenleyebilmesine izin vermektedir. Günümüzde konutiç mekanlarında yap ssistemiyle bağlantılı olan dolaplar haricinde diğer bir çok mobilya elemanı serbest olarak konumlandırılmaktadır. Bu sayede kullanıcılar mobilyalarının yerlerini istedikleri şekilde değiştirebilmektedirler.

Hareketli mobilyanın en sıra dışı örneklerden biri Allan Wexler tasarımı Vinyl Milford Evinde görülmektedir. Seri üretim kulübe, mutfak, banyo, yatma mekanı ve yaşama mekanı içermek için oldukça küçüktür. Duvarlarda mobilyaların formlarına göre açılmış boşluklar sayesinde mobilyalar 
külübenin içine veya dışına doğru hareket ettirilmekte, ihtiyaca göre mekan oluşturulmaktadır. Böylece külübe gündüz bir yaşama mekanı iken gece bir yatma mekanına dönüşebilmektedir ${ }^{3}$.
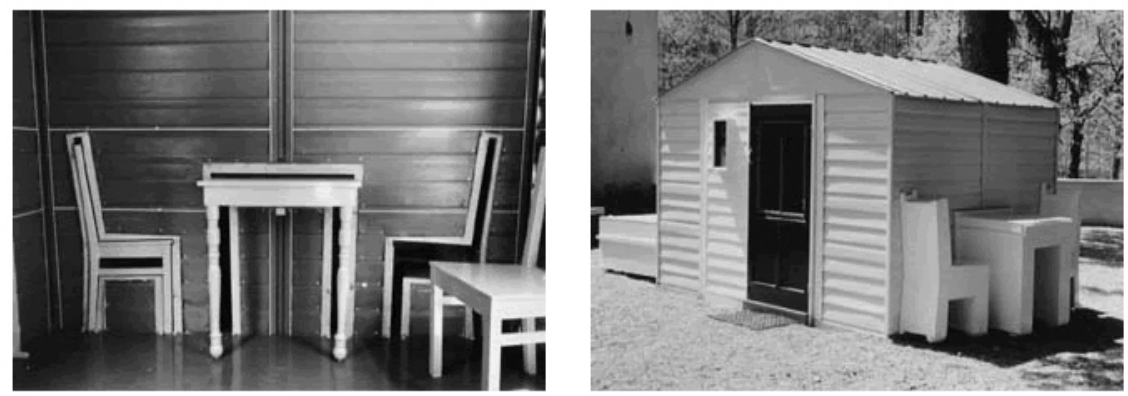

Şekil 2: Vinyl Milford Evi, 19944.

Gün içinde değişen işlevler için kullanılacak mekanlarda; mobilyaların toplanabilir, depolanabilir, hafif olması tercih edilmektedir.

\section{işlevsel Çeşitlilik}

Fonksiyonellik mobilyada bir ihtiyacı karşılama özelliği olarak tanımlanır. Bir konut içerisinde mobilya kullanmanın ana nedeni konut içerisindeki yaşamsal faaliyetler esnasında ortaya çıkan intiyaçları konforlu bir şekilde karşılamaya yöneliktir. Mobilyada birden fazla işlev birleştirilerek "işlevsel çeşitlilik" durumu ortaya çıktıkça mobilyanın o ihtiyacı karşılamak üzere tasarlanması ilkesi esas alınmalıdır.

Mobilyada çok işlevsellik özelliği üç farklı durumu ifade etmek için kullanılmaktadır.

\section{Eylem Alanlarının Üst Üste Bindirilmesi}

Eylem alanlarının üst üste bindirildiği mobilya tasarımında, bir araç aynı anda birden fazla eyleme hizmet etmektedir. Daha çok küçük yaşam alanlarında tercih edilen kompakt mobilyalar kendi içerisinde belirli bir düzende yerleştirilmiş, birçok işlevi bir arada bulunduran komple bir amaca hizmet eden mobilyalardır.

Ömer Ünal tasarımı "Nar" sehpa birleşik fonksiyonlu ürünlere örnek olarak verilebilir. Yan yana sıralanmış ince metal levhalardan oluşan iskelet üzerindeki levhalara kitaplar geçirilerek, sırtlarından dikey olarak

3 http://www.allanwexlerstudio.com

4 http://www.allanwexlerstudio.com 
taşınmaktadır. İskeletin ve kitapların üzerinde rahatlıkla kayabilen tepsiler, kitapları tozdan korumakta ve bir sehpa olarak da kullanım sağlamaktadır.

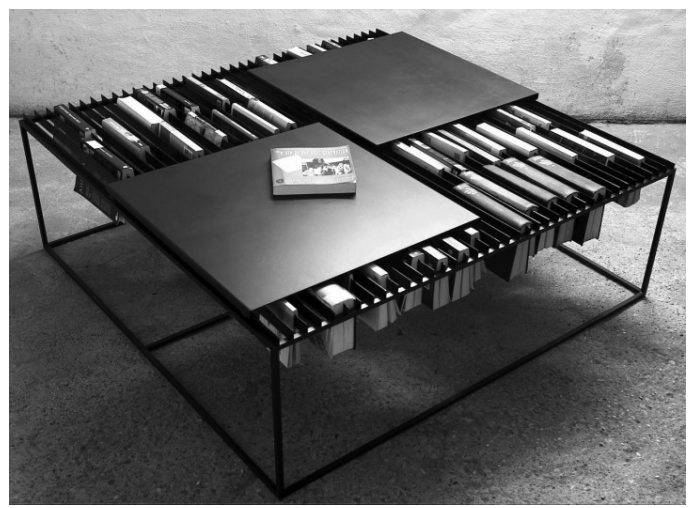

Şekil 3: Nar sehpa, Ömer Ünal,IDW En iyi tasarım ödülü, $2005^{5}$.

\section{Mobilyanın Farklı Zamanlarda Farklı Eylemleri Gerçekleştirebilmesi}

Farklı eylemler için gerçekleştirilen esnek mobilya tasarımı denilince belki de ilk akla gelen mobilyalar, toplumda çek-yat olarak adlandırılan mobilyalardır. Çek-yatlar gün içerisinde oturma ve dinlenme eylemini karşılarken, yapısında hiçbir değişiklik yapılmadan sadece fiziksel özelliği değiştirilerek yatma eylemine araç olmaktadırlar.

\section{Mobilyanın Kullanılmayan Bölümlerine İşlev Yüklenmesi}

Bu tür tasarımlarda mobilyanın kullanılmayan bölümleri ana işlev haricinde farklı işlevler vüklenmektedir.

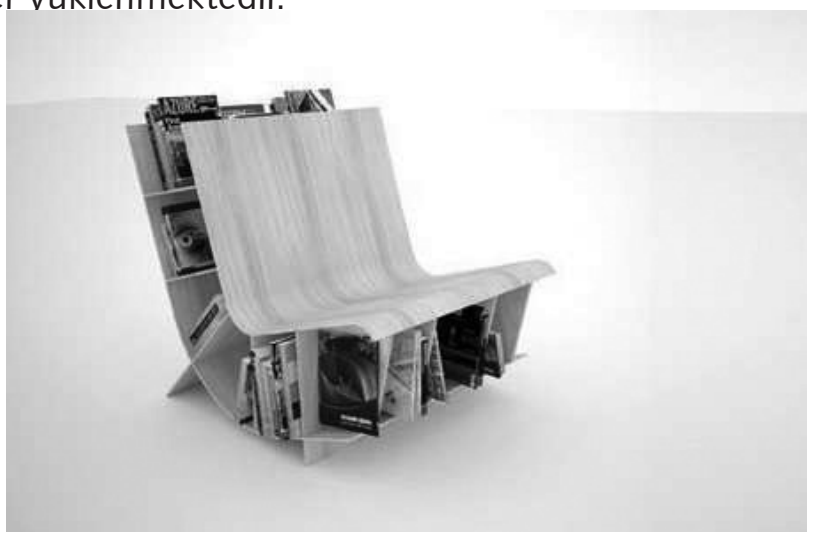

Şekil 4: Mobilyanın kullanılmayan bölümlerine işlev yüklenmesi ${ }^{6}$. 


\section{Modülerlik}

Mobilyada modülerlik, konut içerisinde ortaya çıkan ihtiyaçları farklı oranlarda karşılayacakşekilde oransal bölünmeleryaratarak, ortaya çıkarılan modülleri yan yana ve/veya üst üste getirerek, ihtiyacı tam olarak karşılama sistemi olarak tanımlanır (Burdurlu \& Ejder, 2000). Modüler mobilyalar; kullanııının değişen veya çeşitlenen ihtiyaçlarına cevap verebilmektedir. Modülerlikte amaç mobilyaların tek birimden olmayıp parçadan bütüne gitme mantığının kullanılmasıdır.

Modüler mobilyaların diğer bir özelliği ise birimlerin bir araya gelerek farklı mekanlara uyum sağlayabilen genellikle çok amaçlı ve bütünleşik strüktürler oluşturmalarıdır. Modüler sistemler boyutsal özelliklerinin sağladığı olanaklar ile her yönde çoğalmayı sağlarlar. Zaman içerisinde gerektiğinde mobilya ilavesi veya çıkartması yaparak, bölüp ayırarak veya birleştirerek esnekliği sağladıkları için kira konutlar için uygundur.
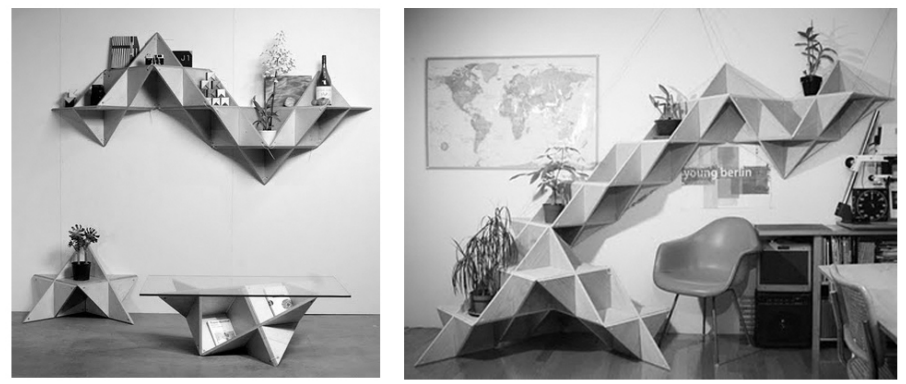

Şekil 5: Modüler mobilya örneği ${ }^{7}$

\section{Toplanabilirlik-Boyut değiştirebilirlik-Depolanabilirlik}

Toplanabilirlik özelliği, mobilyanın kullanılmadığı zamanlarda, mekanda yer kaplamaması amacıyla hacminin küçültülebilmesi olarak tanımlanabilmektedir. Metrekarelerin önemli olduğu günümüz konutunda, kullanıılar yaşam alanlarında kullanmadıkları ya da az kullandıkları nesneleri toplayarak mekanları hacimsel olarak rahatlatmak istemektedirler. Bu noktada hafiflik ve kolay taşınabilirlik devreye girmektedir.

\section{Mobilyanın katlanarak toplanması}

Ergonomik açıdan, katlanan mobilyaların hafif malzemeden üretilmiş olmaları gerekmektedir. Mekanda kullanım alanının artırılması isteği uğruna gereğinden ağır olan mobilyaların katlanabilir nitelikte olması yanlış bir düzenleme şeklidir. Fazla ağıllık kullanıcıda katlama güçlüğüne

7 http://www.mobilyadekorasyonrehberi.com 
sebep olduğu gibi mobilyanın bağlantı yerlerini de esnetebilir.
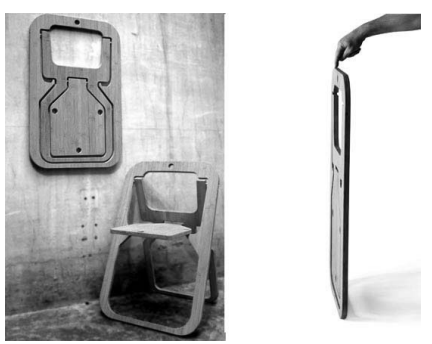

Şekil 6: Katlanır sandalye, Christian Desile ${ }^{8}$.

Mobilya bileşenlerinin iç içe geçerek toplanması

İçiçe geçerek toplanma özelliği ile mobilya gerektiği zamanda kendi içerisinde bir hacim oluşturmuş olur ve konut iç mekanında yer kaplamamış olur.

Matt'ın birleştirilebilir koltuk tasarımında çeşitli formlardaki minderlerin kullanılmadıkları zaman toplanıp kompaktlaşması ile mekan kazanımı amaçlanmıştır.

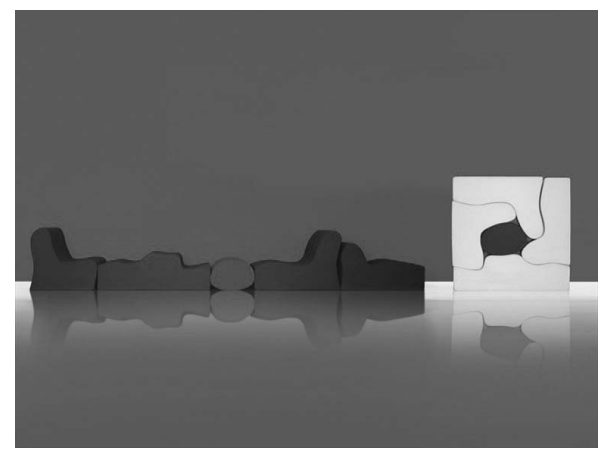

Şekil 7: Birleştirilebilir koltuk, Sebastiano Matt, $1966^{9}$

\section{B. Tasarım Özellikleri}

Konut iç mekanı ve mobilya etkileşimi bağlamında mobilya tasarım özellikleri araştırıldığında, ilk olarak geometri ile karşılaşılmaktadır. Günümüz mobilya tasarımında; sıkıkla rastlanan, temelini Bauhaus'tan alan temel geometrilerin yanı sıra temelini temel geometrilerden referans alan farklı formlar ve amorf hareketler de kabul görmüştür. 
Alessandro Mendini'nin 1985 yılında Baleriltalia firması için tasarladığı Karina isimli sıra oturma, rasyonel ve temel geometrilerin kullanıldığı bir örnektir. Yarım çember şeklindeki sırt ve arka ayakları oluşturan parça, dik açılı kayıtlarla birleştirilmiştir. Dikdörtgen biçimli oturak ise ferforje çelik sacdan yapılmıştır.

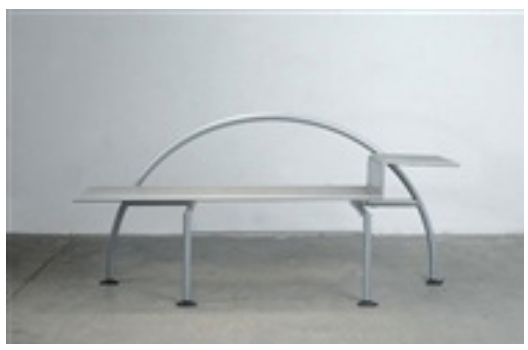

Şekil 8: Karina, Alessandro Mendini, $1985^{10}$.

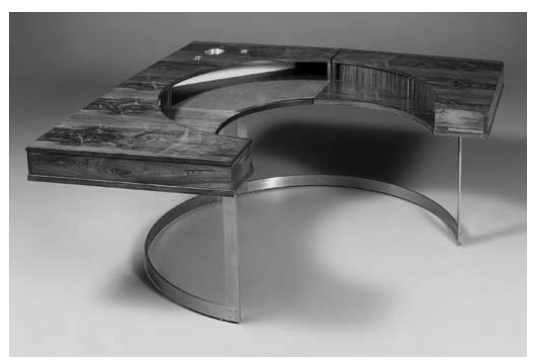

Şekil 9: FabioLenci, 1970"1.

Benzer bir parça örnek, FabioLenci'nin 1970 yılında tasarladığı masada göze çarpmaktadır. Ürün, iki boyuttaki şekillerin üçüncü boyuta mobilya ile aktarılmasını simgeler niteliktedir. Masanın ayakları mekândaki yüzey devamlılığını bozmayacak şekilde çelik profilden üretilmiştir.

Temel geometrilerle tasarlanan mobilyalardan farklı bir örnek olarak Morten Brorsen'in komodin tasarımı incelenebilir. Ürünün tasarımında eğrisel formlar hâkimdir ancak eğrisel formlar yarım ve çeyrek çemberlerden referansla oluşturulmuştur. Eğriselliklerin, temel geometrik formların yardımıyla oluşturulması, mobilya üretiminde hız ve verimlilik sağlayacaktır. (Gura, 2007)

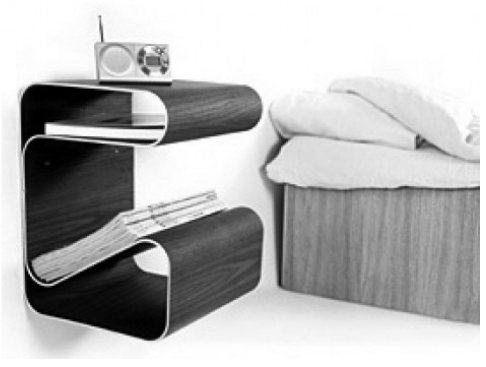

Şekil 10: Morten Brorsen, 2002 (Gura,2007)

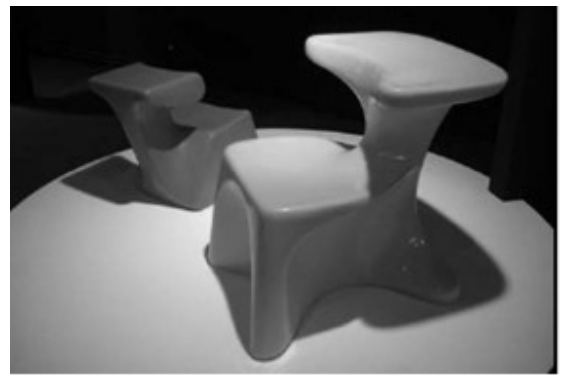

Şekil 11: Colani tasarımları'12

Colani organik tasarımlarının felsefesini şu şekilde özetlemiştir: "Dünyanın yuvarlak olduğunu biliyorum, tüm gök cisimlerinin yuvarlak olduğunu,

10 www.designmuseum.org

I I www.designmuseum.org

12 www.colani.org 
onların yuvarlak veya eliptik yörünge üzerindeki tüm hareketlerinin dairesel şekilde olduğunu biliyorum. Aynı görüntü mikro kozmostan aşağıya doğru bizi takip ediyor. Buna rağmen neden her şeyi dikdörtgen ve köşeli yapmak isteyenlerin grubuna katılayım? Ben Galileo felsefesinden gidiyorum: Benim dünyamda yuvarlaktır"13.

Tasarım özellikleri altında değinilmesi gereken bir diğer nitelik ise ürünün boşluk doluluk dengesidir. Mekânda kullanılan mobilyanın boşluk doluluk dengesi, mekân algısını doğrudan etkilemektedir. Boşluk-doluluk dengesi bir mekânda hem işlevsel hem de estetik açıdan ele alınmalıdır. Kütlesel etkisi olmayan mobilyalar ile mekân işgal edilmediği dolayısıyla küçülmediği için hacmin kullanımı artmaktadır. Bu nedenle bu tür mobilyaları görünmez olarak nitelemek mümkündür.

Mekanda yüzey algısını vurgulamak diğer bir deyişle mekanın iç hacminin bir bütün olarak algılanmasını sağlamak; çizgisel ve hafif mobilyalar ile mümkün olmaktadır. Marcel Breuer'in tasarladığı iki farklı mobilya üzerinden mekansal algıları karşılaştırmak fikir vermek açısından iyi olacaktır. Breuer'in Sommerfield Evi için tasarladığı masif ahşap mobilyalar, hantal görüntüleri ile mekanda görsel bir engel niteliğinde kalmıştır.
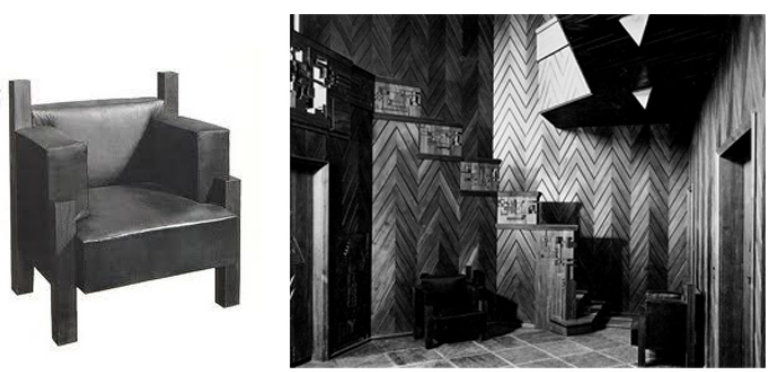

Şekil 12: Sommerfield Evi, $1920^{14}$.

Breuer'in Piscator Apartmanı için tasarladığı mobilyalar ise hafiflikleri ve çizgisellikleri ile mekandaki boşluğa vurgu yapmaktadır. Böylece görsel akışkanlığı olan geniş, sade ve özgür yaşam alanları elde edilmiştir. Bruer değişen mobilya ile mekan ilişkisini şu şekilde açıklamıştır: "Mobilya artık hantal, büyük, zemine bağlı veya gömme değil. Mobilya artık hafifleyerek yerden koptu, ne odadaki harekete engel oluyor ne de görüşü engelliyor" (Wilk, 2006).

13 www.colani.org

14 www.designmuseum.org 


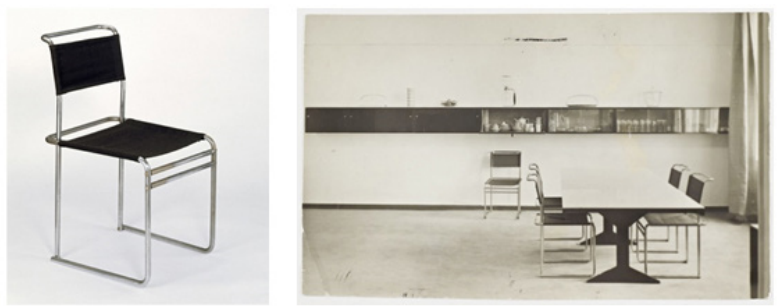

Şekil 13: Piscator Apartmanı, 1927 (Wilk, 2006)

Mobilya tasarımında ürünün varlığını tariflemeye yarayan, ürünü hayata geçiren malzeme çok önemlidir. Mobilyaların yüzeyleri, insanla fiziksel ve görsel ilişki kuran, dolayısıyla ilk algılanan noktalarıdır.

Mobilya denildiğinde genellikle gözümüzde canlanan, ahşaptan yapılmış bir üründür. Bu durumun sebebi, ahşabın geçmişten günümüze mobilya üretiminde en çok kullanılan malzeme olmasıdır. Ahşap doğanın sunduğu organik esaslı bir malzemedir, konut iç mekan mobilyalarında çok geniş alanda kullanım olanağı vardır.

Doğal taşın ana karakteri ise ağır olmasıdır. Bu karakter beraberinde durağanlık kavramını getirmektedir. Taş yapısı gereği daha çok dış mekan mobilyalarında kullanılırken, Marco Zanini'nin sehpa tasarımlarında olduğu gibi cam ve metal gibi diğer malzemeler ile birlikte yorumlanarak iç mekanlarda da göze çarpmaktadır. Peter Dieterich tasarımı "Seco" çalışma masasında ise alışılagelmiş ayak formları yerine, malzemenin niteliği göz önünde tutularak düşey ve yatay iki blok mermer kullanılmıştır.

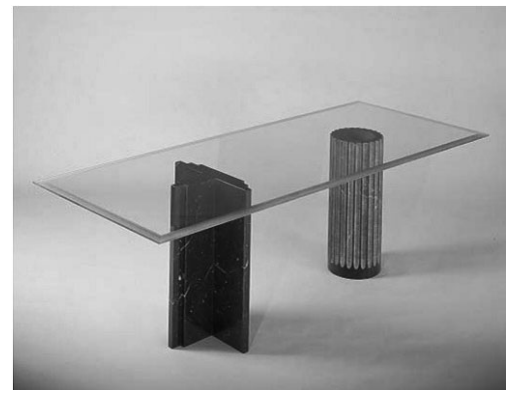

Şekil 14: Sehpa, Adolfo Natini ${ }^{15}$

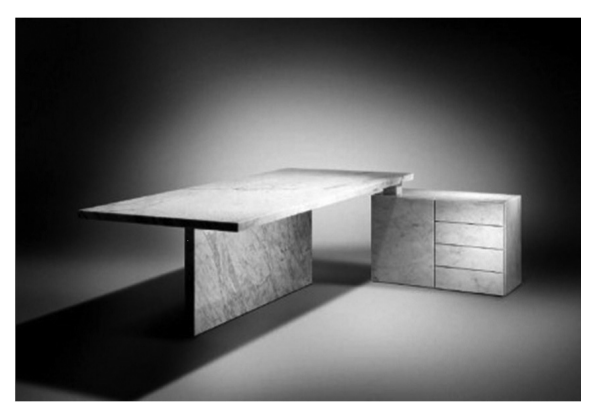

Şekil 15: Çalışma masası, Peter Dieterich ${ }^{16}$

Plastik malzemeler çok yönlü kullanıma sahip, maliyet performansı yüksek ve hafiftirler. Plastik malzemeden üretilen mobilyalar özellikle hafiflikleri nedeniyle hareket ve kullanım kolaylığı sağlamaktadır. Ayrıca plastik

15 www.designmuseum.org 16 www.designmuseum.org 
kalıplama tekniğine uygunluğu sebebiyle seri üretimi olanaklı kılmış, tek bir kalıp ile aynı kalite ve aynı biçimde pek çok ürünü maliyeti düşük olarak elde etme olanağı sağlamıştır (Onur, 2000).

Geçmişte birleştirme elemanı, süs öğesi ve taşıyıcı olarak kullanılan metal malzeme, günümüzde tamamen bir mobilyayı oluşturmada da kullanılmaktadır. Tunç, altın, gümüş ve demir geçmiş dönemlerin, çelik ve alüminyum ise günümüzün mobilya yapımında en çok kullanılan metalleridir. Metalin esnek ve buna rağmen dayanıklı olması, mobilya tasarımına yeni olanaklar getirmiştir. Metaller, istenen biçimlere kolayca girebilen malzemelerdir. Yeni üretim teknolojileriyle de tasarım olanakları genişlemektedir.
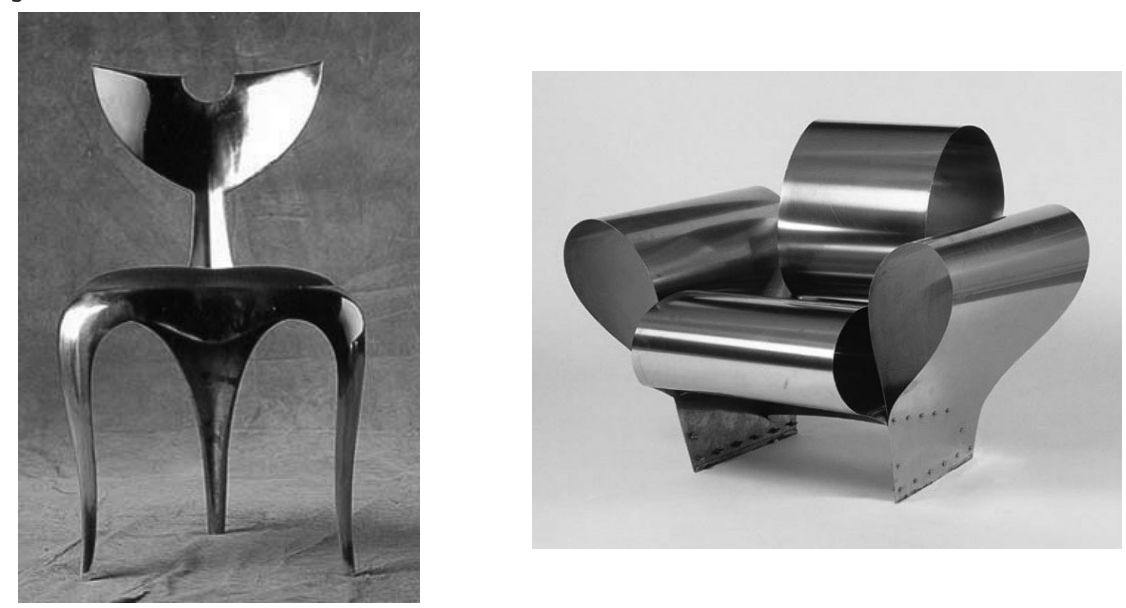

Şekil 16. Whaletail, Mark Brazier-Jones, 198917. Şekil 17. Welltemperedchair, RonArad, 1986 ${ }^{18}$.

\section{Sonuç ve Öneriler}

Bu çalışmada konut tasarım üretim süreci ile mobilya tasarım-üretim süreci arasındaki çok boyutlu ilişkiler ağına vurgu yaparak, Türkiye ölçeğinde "mobil hane halkı" ve "kira konut" kavramları üzerinden konut içinde kullanılan mobilyaların özellikleri, iki ana başlık altında incelenmiş̧ir. İki ana başlık, çalışmanın problem alanını oluşturan kiracı olma oranının yüksek olduğu ve hane halklarının sıklıkla konut değiştirdiği durumlar gözetilerek belirlenmiştir.

Mobilyanın işlevsel özellikleri başlığı altında incelenen sabitlik/hareketlilik, işlevsel çeşitlilik, modülerlik, toplanabilirlik / boyut değiştirebilirlik / depolanabilirlik özellikleri örneklerle açıklanmış, mobilyanın "esneklik" niteliğinin bütün alt başlıkları kapsayan bir nitelik olduğu görülmüştür. 
Mobilyanın tasarım özellikleri başlığı altında incelenen geometri, boşluk doluluk dengesi ve malzeme nitelikleri örneklerle açıklanmış, mekan ile ilişkileri bağlamında tartışılmıştır.

Sonuç olarak; mekanlar ve mekanların tamamlayıcı öğeleri olan mobilyalar, birbirleriyle etkileşim içindedir. Konut iç mekanları ile bu mekanlardaki yaşamsal faaliyetleri kolaylaştırması amacıyla üretilen mobilyaların uyumu kiracılık, sık konut değiştirme, her konuta göre yeni mobilya alamama, fiyat öncelikle konut ve mobilya seçimi gibi pek çok sebepten dolayı sağlanamamaktadır. Herhangi bir uyumsuzluk durumu kullanıcının mutsuz olmasına ve memnuniyetsizliğin başlamasına sebep olabilmektedir. Kullanıcılar memnuniyetsizliklerini kendilerince gidermeye çalışmaktadır. Ancakmobilyanın içinde bulunduğumekanile uyum sorununun çözümünde mobilya ve mekan niteliğine dair çeşitli önerilerde bulunulabilir:

- Konut tasarım ve üretiminin bina tasarlama eyleminden öte; kullanıcı için yaratılan bir yaşam tarzı olduğu düşünülmelidir. Konut, kişinin yuvası, gündelik yaşamındaki sığınağı, benliğinin ve kişiliğinin şekillenmesinde en temel rolü oynayan yer ve değer verdiği nesnelerin, eşyaların ve anılarının koruyucusudur (Pink, 2004; Miller, 2001). Dolayısıyla ön görülen yaşam tarzının iç mekana yansıtılması gerekmektedir.

- Konut tasarım ve üretiminin de; binanın tasarımı kadar yaratılan her bir mekanın niteliği de göz önünde bulundurulmalıdır. Günümüz şartlarında mimari tasarım sürecinde bilgi ve sorumluluk dağılımına, dolayısıyla çok disiplinli ekiplere ihtiyaç duyulduğu görülmektedir.

- İ̧ mekan tasarım sürecinde, mekanın formu, büyüklügü̈, sirkülasyon şeması, cephe boşluğu vb. yapısal özelliklerin o mekanda kullanılabilecek donatı özelliklerini etkilediği unutulmamalıdır. Mobilya tasarım süreci mekan tasarım sürecini etkilemeli; mimarlar mobilya endüstrisi ile işbirliği içinde olmalıdır.

- Konut iç mekân tasarımda mobilyanın önemli bir girdi olarak değerlendirilmesi gerektiği gibi; mobilya tasarım sürecinde de konut iç mekan özelliklerinin dikkate alınması gerekmektedir.

- Ortak kullanıı için konut ve mobilyanın tasarım süreçleri birbirinden etkilenmelidir. 


\section{Kaynakça}

Burdurlu \& Ejder. (2000). Dar Hacimli Konutlara Uygun Modüler Mobilya Tasarımı, Mobilya Dekorasyon Dergisi, Sayı 38.

Byars, M. (2005). The Best Tables, Chairs, Lights: Innovationa And Invention In Design Products For The Home. Hovo, Rotovision.

Ching, F.D.K. (2007). Architecture: Form, Space, Order. USA, John Wiley\&Sons.

Günay, R. (1998). Türk Ev Geleneği ve Safranbolu Evleri. İstanbul. YEM Yayınları.

Gura, J. (2007). Sourcebook of Scandinavian Furniture: Designs for the 21 st Century. New York, W.W.Norton Company.

Karahan, E.E. (2009). Konut Talebinin Modellenmesi ve Konut Kariyer Kavramı, İstanbul Ticaret Üniversitesi Fen Bilimleri Dergisi, Sayı 15.

Karasar, N. (2007). Bilimsel Araştırma Yöntemi, Ankara: Nobel Yayınları.

Miller, D. (2001). Home possessions: Material Culture Behind Closed Doors, Oxford, Berg Yayınları.

Milliyet Hachette Axis 2000 Büyük Ansiklopesi, Doğan Kitapçılık.

Onur, S. (2000). Mobilya Biçimlenişine Etki Eden Faktörler ve Tasarımcı Kullanıcı Faktörü Üzerine Bir Yöntem Önerisi, Doktora Tezi, Mimar Sinan Üniversitesi, İstanbul.

Pink, S. (2004). Home Truths: Gender, Domestic Objects and Everyday Life, Oxford, Berg Yayınları.

T.C. Başbakanlık Aile Araştırma Kurumu Başkanlığı. (1999). Türk Ailesinin Yaşadığı Mekânlara / Konutlara İlişkin Eğilimler. Cilt 1-2, Ankara, Başbakanlık Basımevi.

\section{Internet Kaynakları}

http://www.kulturvarliklari.gov.tr

http://www.tdk.gov.tr

\section{Görsel Kaynakları}

Şekil 1: Günay, R. (1998). Türk Ev Geleneği ve Safranbolu Evleri. İstanbul. YEM Yayınları.

Şekil 2 : http://www.allanwexlerstudio.com

Şekil 3: http://www.omerunal.com 
Şekil 4-5: http://mobilyadekorasyonrehberi.com

Şekil 6: http://www.designbuzz.com

Şekil 7: http://www.archiproducts.com

Şekil 8-9-12-14-15-16-17: http://www.designmuseum.org

Şekil 10: Gura, J. (2007). Sourcebook of Scandinavian Furniture: Designs for the 21st Century. New York, W.W.Norton Company.

Şekil 11: http://www.colani.org

Şekil 13: Wilk, C. (2006). Modernism : Designing A New World : 1914-1939. London : V\&A Publications. 